\title{
A Conceptual Cost Benefit Analysis of Tailings Matrices Use in Construction Applications
}

\author{
Ali A. Mahmood ${ }^{1, a}$ and Maria Elektorowicz ${ }^{2}$ \\ ${ }^{1}$ Department of Civil Engineering, University College of Technology Sarawak, 96000 Sibu, Sarawak, Malaysia \\ ${ }^{2}$ Department of Building Civil and Environmental Engineering, Concordia University, Montreal, Quebec, H3G 1M8, \\ Canada
}

\begin{abstract}
As part of a comprehensive research program, new tailings matrices are formulated of combinations of tailings and binder materials. The research program encompasses experimental and numerical analysis of the tailings matrices to investigate the feasibility of using them as construction materials in cold climates. This paper discusses a conceptual cost benefit analysis for the use of these new materials. It is shown here that the financial benefits of using the proposed new tailings matrices in terms of environmental sustainability are much higher when compared to normal sand matrices.
\end{abstract}

\section{Introduction}

Mine tailings are the leftovers from mining activity and they contain all the hazardous materials used in the milling process with the exception of the ore. Tailings are traditionally stored in ponds not far away from the mine they originated from. Mine tailings have been the subject of several environmental catastrophes such as the Merriespruit dam tailings failure that resulted in the deaths of 17 people and extensive damages to a residential township in South Africa in 1994 (Fourie and Papageorgiou [1] and Fourie et al. [2]). Another disaster took place in the Philippines in 2002 were tailings spilled into Mapanuepe Lake and eventually into the Saint Tomas river. Low lying villages were flooded with mine waste. At least 250 families were evacuated from that area [3].

Researchers around the world, having realized the potential dangers involved in the traditional method of storage of mine tailings in ponds, took up the task of attempting to beneficially re-use these tailings or at least modify them in a way less harmful to the environment. Researchers like Demers and Haile [4], Zou and Sahito [5] Celik et al. [6] Swami et al. [7] and Roy et al. [8] attempted to investigate the possibility of using mine tailings as filler or construction materials with the addition of binders that include Portland cement. Other researchers like Fall et al. [9], Fall et al. [10], Benzaazoua et al. [11], Ercikdi et al. [12], Fall and Pokharel [13], Ercikdi et al. [14] and Helinski et al. [15] investigated the use of mine tailings in the most traditional manner by using them as cemented paste backfill. Portland cement, however, is relatively expensive, hence the need to use additives other than cement to reduce cost without compromising effectiveness. This effectiveness is specifically important in cold climates such as that of Canada.

\footnotetext{
${ }^{a}$ Corresponding author : ali.mahmood@ucts.edu.my
} 
Calsifrit is a special cementitious material that was developed recently by NovaFrit International [16]. It is a totally amorphous material, a matrix of calcium and sodium fluoro-aluminosilicate. It is a homogenous solid substance possessing high reactivity potential and shows cementitious properties when finely ground. Calsifrit will be used in conjunction with slag and fly ash as Portland cement replacements mixed with mine tailings. These combinations will form the mine tailings matrices under consideration herein. No research to date has been published on the conceptual cost benefit analysis of using mine tailings-Calsifrit matrices in construction.

This paper discusses a conceptual cost benefit analysis of re-using these mine tailings matrices in the construction of road bases. This analysis is part of a broader and more comprehensive experimental and numerical research program into the re-use of mine tailings matrices as construction materials in cold regions [17].

\section{Conceptual Framework}

A cost benefit analysis example on the use of these tailing matrices in construction is given here. This cost benefit analysis is implemented to ascertain the benefits involved in the use of these tailing matrices in the road construction industry. This analysis is primarily based on the environmental sustainability that the use of these matrices carries in comparison with the traditional, soil based methods.

This section attempts to quantitatively outline some of the benefits involved in the use of tailings matrices in construction, specifically road construction. In the current study, it is thought that the following approach is the best for this study and will be adopted by the identification of materials and costs and benefits, quantification of costs and benefits and then, that will be followed by the discussion and conclusion.

The two types of materials involved that make up the cost benefit analysis comparison are the following:

a. The tailing matrices including Ordinary Portland Cement (OPC), Calsifrit, fly ash and slag

b. Granular material normally used as sub-base in roads [18]

It is assumed in this analysis that two typical road sub-base sections are built that incorporate either one of these materials. The following is the identification of costs and benefits:

Benefits:

a. Tailings dusting is fully eliminated using this new technique. This dusting is considered a serious environmental incident prompting Hudson's Bay Mining and Smelting Company Limited to issue a control guidelines report for their tailings impoundment systems [19]

b. Failure of tailings dams with all the imposed hazards due to the traditional storage of tailings in ponds. A study by Rico et al. [20] reports 147 worldwide tailings dam disasters. Once the solidified/stabilized tailings matrices are in-place, this hazard is eliminated, thereby saving lives and property that are otherwise prone to tailings dangers

c. Heavy metal seepage to the ground water table is eliminated or much reduced by this approach of stabilizing/solidifying the tailings material

d. Freeing up the space previously occupied by the tailings dam

e. Freeing up resources and personnel connected with the supervision on the tailings dam

f. Using up industrial wastes such as fly ash and slag

g. Using Calsifrit, identified above

\section{Costs:}

a. Trucks to transfer to the site the tailings from local mines in the area

b. Machinery that spread and compact the tailings in the base course layer to the required thickness and density

c. Specialized workforce

d. Importation of $\mathrm{OPC}$ 


\section{Discussion}

Cost benefit analysis attempts to put a monetary value on all items included in the analysis. However, this section is more focused on a conceptual quantitative analysis related to the environmental sustainability of the tailings matrices and their effects. Hence a procedure explained by Shutt [21] and used and cited by Amjad [22] will be used here whereby symbols will be given based on the importance priority of each cost or benefit item.

Amjad [22] performed a cost benefit analysis for three potential alternatives for a road construction project through an industrial-residential town. He was able to demonstrate through the use of a combined conceptual-monetary approach the financial implication of each alternative and the best solution for the problem.

When analyzing environmental issues, it is often difficult to assign explicit monetary values to the gains associated with sustainability schemes. Therefore, based on that, and in order to quantify the unquantifiable, it is decided here to assign an abbreviation for each of the following basic values: $M$ for monetary benefits, $\mathrm{S}$ for increased safety, I for intangibles and $\mathrm{T}$ for time saving. These abbreviations denote annual flow of cost or benefit. Also, a plus sign $(+)$ will be added to denote benefits and a minus (-) to denote costs. A duplication of the sign will indicate added importance. Tables 1 and 2 show the benefits and costs associated with this approach for the tailings and sand matrices respectively.

Table 1. Cost benefit analysis of the use of tailings matrices.

\begin{tabular}{|l|c|c|c|}
\hline \multicolumn{1}{|c|}{ Factor } & Benefits & Costs & Balance \\
\hline Tailings dusting & $\mathrm{S}+\mathrm{I}+$ & & $\mathrm{S}+\mathrm{I}+$ \\
\hline Tailings dam failures & $\mathrm{S}++\mathrm{M}+\mathrm{T}+$ & & $\mathrm{S}++\mathrm{M}+\mathrm{T}+$ \\
\hline Heavy metal seepage to the ground water & $\mathrm{S}+\mathrm{M}+\mathrm{T}+$ & & $\mathrm{S}+\mathrm{M}+\mathrm{T}+$ \\
\hline $\begin{array}{l}\text { Freeing up the space previously occupied by the tailings } \\
\text { dam }\end{array}$ & $\mathrm{M}+$ & & $\mathrm{M}+$ \\
\hline $\begin{array}{l}\text { Freeing up resources and personnel connected with the } \\
\text { supervision on the tailings dam }\end{array}$ & $\mathrm{M}+\mathrm{T}+\mathrm{I}+$ & & $\mathrm{M}+\mathrm{T}+\mathrm{I}+$ \\
\hline Fly ash & $\mathrm{S}+$ & $\mathrm{M}-$ & $\mathrm{S}+\mathrm{M}-$ \\
\hline Calsifrit & $\mathrm{S}+$ & $\mathrm{M}-$ & $\mathrm{S}+\mathrm{M}-$ \\
\hline Slag & $\mathrm{S}+$ & $\mathrm{M}-$ & $\mathrm{S}+\mathrm{M}-$ \\
\hline Trucks & & $\mathrm{M}-$ & $\mathrm{M}-$ \\
\hline Machinery & & $\mathrm{M}-$ & $\mathrm{M}-$ \\
\hline Workforce & & $\mathrm{M}-$ & $\mathrm{M}-$ \\
\hline On Site Delivery & $\mathrm{M}+$ & & $\mathrm{M}+$ \\
\hline Importing OPC & & $\mathrm{M}-$ & $\mathrm{M}-$ \\
\hline
\end{tabular}

M: monetary benefits, $\mathrm{S}$ : increased safety, T: time saving, I: intangibles

Table 2. Cost Benefit Analysis of the use of sand matrice

\begin{tabular}{|l|c|c|c|}
\hline \multicolumn{1}{|c|}{ Factor } & Benefits & Costs & Balance \\
\hline Fly ash & S+ & M- & S+ M- \\
\hline Calsifrit & S+ & M- & S+ M- \\
\hline Slag & S+ & M- & S+ M- \\
\hline Trucks & & M- & M- \\
\hline Machinery & & M- & M- \\
\hline Workforce & & M- & M- \\
\hline On Site Delivery & & M- & M- \\
\hline Importing OPC & & M- & M- \\
\hline
\end{tabular}

M: monetary benefits, $\mathrm{S}$ : increased safety, T: time saving, I: intangibles

It is seen through Table 3 that the financial implications of using the sand matrices are higher than those of the tailings matrices. 
Table 3. Summary of findings and order of preference.

\begin{tabular}{|c|c|c|c|c|}
\hline \multirow[b]{2}{*}{ Factor } & \multirow[b]{2}{*}{$\begin{array}{l}\text { Tailings } \\
\text { Matrices }\end{array}$} & \multirow[b]{2}{*}{$\begin{array}{c}\text { Sand } \\
\text { Matrices }\end{array}$} & \multicolumn{2}{|c|}{ Order of Preference } \\
\hline & & & $\begin{array}{c}\text { Tailings } \\
\text { Matrices }\end{array}$ & $\begin{array}{c}\text { Sand } \\
\text { Matrices }\end{array}$ \\
\hline Tailings dusting & $\mathrm{S}+\mathrm{I}+$ & - & 1 & 2 \\
\hline Tailings dam failures & $\mathrm{S}++\mathrm{M}+\mathrm{T}+$ & - & 1 & 2 \\
\hline $\begin{array}{l}\text { Heavy metal seepage to the ground } \\
\text { water }\end{array}$ & $\mathrm{S}+\mathrm{M}+\mathrm{T}+$ & - & 1 & 2 \\
\hline $\begin{array}{l}\text { Freeing up the space previously } \\
\text { occupied by the tailings dam }\end{array}$ & $\mathrm{M}+$ & - & 1 & 2 \\
\hline $\begin{array}{l}\text { Freeing up resources and personnel } \\
\text { connected with the supervision on } \\
\text { the tailings dam }\end{array}$ & $\mathrm{M}+\mathrm{T}+\mathrm{I}+$ & - & 1 & 2 \\
\hline Fly ash & $\mathrm{S}+\mathrm{M}-$ & $\mathrm{S}+\mathrm{M}-$ & 1 & 1 \\
\hline Calsifrit & $\mathrm{S}+\mathrm{M}-$ & $\mathrm{S}+\mathrm{M}-$ & 1 & 1 \\
\hline Slag & $\mathrm{S}+\mathrm{M}-$ & $\mathrm{S}+\mathrm{M}-$ & 1 & 1 \\
\hline Trucks & M- & M- & 1 & 1 \\
\hline Machinery & M- & M- & 1 & 1 \\
\hline Workforce & M- & $\mathrm{M}-$ & 1 & 1 \\
\hline On Site Delivery & $\mathrm{M}+$ & M- & 1 & 2 \\
\hline Importing OPC & M- & M- & 1 & 1 \\
\hline \multicolumn{3}{|l|}{ Preference Totals } & 13 & 19 \\
\hline \multicolumn{3}{|l|}{ Overall Order of Preference } & 1 & 2 \\
\hline
\end{tabular}

M: monetary benefits, S: increased safety, T: time saving, I: intangibles

\section{Conclusion}

It can be seen that financial benefits in terms of environmental sustainability are much higher for the tailings matrices in comparison to normal sand matrices. Consequently, it can be concluded that tailings matrices present a higher sustainability priority material for use in road sub-bases.

\section{References}

[1] A.B. Fourie and G. Papageorgiou, Defining an appropriate steady state line for Merriespruit gold tailings, Canadian Geotechnical Journal, 38(4), 695-706, (2001).

[2] A.B. Fourie, G.E Blight and G. Papageorgiou, Static liquefaction as a possible explanation for the Merriespruit tailings dam failure, Canadian Geotechnical Journal, 38(4), 707-719, (2001).

[3] Wise, World Information Service on Energy-Uranium Project, (2012). <available at: http://www.wise-uranium.org/index.html>

[4] B. Demers and G. Haile, Management of tailings stabilized by lime and cement at Canadian electrolytic zinc, Valleyfield, Quebec, Proc. of Sudbury 2003 Mining and the Environment, Sudbury, Ontario, (2003).

[5] D.H. Zou and W. Sahito, Suitability of mine tailings for shotcrete as a ground support, Canadian Journal of Civil Engineering, 31(4), 632-636, (2004).

[6] O. Celik, I.Y. Elbeyli and S. Piskin, Utilization of gold tailings as an additive in Portland cement, Waste Management and Research, 24(3), 215-224, (2006).

[7] R.K. Swami, N.K.S. Pundhir and S. Mathur, Kimberlite tailings a road construction material, Transportation Research Record: Journal of the Transportation Research Board, 2(1989), 131134, (2007).

[8] S. Roy, G.R. Adhikari and R.N. Gupta, Use of gold mill tailings in making bricks, a feasibility study, Waste Management and Research, 25(5), 475-482, (2007), 
[9] M. Fall, M. Benzaazoua and S. Ouellet, Experimental characterization of the influence of tailings fineness and density on the quality of cemented paste backfill, Minerals Engineering, 18(1), 4144, (2005).

[10]M. Fall, M. Benzaazoua and E.G. Saa, Mix proportioning of underground cemented tailings backfill, Tunnelling and Underground Space Technology, 23(1), 80-90, (2008).

[11] M. Benzaazoua, B. Bussiere, I. Demers, M. Aubertin, E. Fried and A. Blier, Integrated mine tailings management by combining environmental desulphurization and cemented paste backfill, Application to mine Doyon, Quebec, Canada, Minerals Engineering, 21(4), 330-340, (2008).

[12]B. Ercikdi, A. Kesimal, F. Cihangir, H. Deveci and I. Alp, Cemented paste backfill of sulphiderich tailings, importance of binder type and dosage, Cement and Concrete Composites, 31(4), 268-274, (2009).

[13]M. Fall and M. Pokharel, Coupled effects of sulphate and temperature on the strength development of cemented tailings backfills, Portland cement-paste backfill, Cement and Concrete Composites, 32(10), 819-828, (2010).

[14]B. Ercikdi, F. Cihangir, A. Kesimal, H. Deveci and I. Alp, Effect of natural pozzolans as mineral admixture on the performance of cemented-paste backfill of sulphide-rich tailings, Waste Management and Research, 28(5), 430-435, (2010).

[15]M. Helinski, M. Fahey and A. Fourie, Coupled two-dimensional finite element modeling of mine backfilling with cemented tailings, Canadian Geotechnical Journal, 47(11), 1187-1200, (2010).

[16] NovaFrit International, 1200 Garnier Street, Ville Ste-Catherine, Quebec, J0L 1E0, (2010).

[17]A.A. Mahmood, Experimental and computational assessment of tailings binder matrices for construction purposes in cold regions, PhD Thesis, Concordia University, Montreal, (2012).

[18]Foth and Van Dyke Associates, All season road construction cost analysis-Clark County, Wisconsin, Technical Report, Wisconsin, (2003).

[19]Hudson Bay Mining and Smelting Co. Limited, FFTIS Dust Control Guidelines, Document No. LAI-612, Flin Flon, Manitoba, (2007).

[20]M. Rico, G. Benito, A.R. Salgueiro, A. Díez-Herrero and H.G. Pereira, Reported tailings dam failures, a review of the European incidents in the worldwide context, Journal of Hazardous Materials, 152(2), 846-852, (2008).

[21]R.C. Shutt, Economics for the construction industry, Addison Wesley Long Man Limited, Harlow, Essex, (1997).

[22]A.A. Amjad, Cost benefit analysis for construction projects, IEP-SAC Journal, 85-90, (2005). 